\section{International Scientific Journal Theoretical \& Applied Science}

\author{
p-ISSN: 2308-4944 (print) e-ISSN: 2409-0085 (online) \\ Year: $2016 \quad$ Issue: $12 \quad$ Volume: 44 \\ Published: $30.12 .2016 \quad$ http://T-Science.org
}

SECTION 8. Architecture and construction.
Viktor A. Sakhnovsky

the chief architect of the project, the head of the bureau, Architectural bureau of Sakhnovsky,

Saint-Petersburg, Russia info@archms.ru

Igor N. Polovtsev

chief engineer of the project, CEO, Architectural bureau of Sakhnovsky,

Saint-Petersburg, Russia i.polovtsev@archms.ru

Tatiana V. Antonova Architect-restorer, Architectural bureau of Sakhnovsky,

Saint-Petersburg, Russia tatiana.antonova90@mail.ru

\title{
NEW PREMISES FOR EXPOSITION OF THE STATE RUSSIAN MUSEUM IN SAINT-PETERSBURG
} \begin{abstract}
culture, protection of monuments, design, architecture.
Language: English 114.

\section{Introduction}

The State Russian Museum in Saint-Petersburg - one of the largest Russian art museums. By the number of items, it even surpasses the famous Louvre (410, 000 storage units against 300 thousand in the Louvre). However, significantly inferior to it in the area (120 thousand square meters in the Louvre / 34.4 thousand square meters in the main building complex of the Russian Museum in Arts Square) and attendance (9.2 million / 1.2 million visitors per year) [1-3].
\end{abstract}

Abstract: The article describes the architectural project to increase exhibition space for the State Russian Museum. This Museum is the largest art Museum that stores works by Russian artists. As a result of building of two courtyards, the Museum gets new exhibit space and new ways of moving visitors.

Key words: Museum, reconstruction, of the Museum building, the exhibition space, monuments of history and

Citation: Sakhnovsky VA, Polovtsev IN, Antonova TV (2016) NEW PREMISES FOR EXPOSITION OF THE STATE RUSSIAN MUSEUM IN SAINT-PETERSBURG. ISJ Theoretical \& Applied Science, 12 (44): 106-

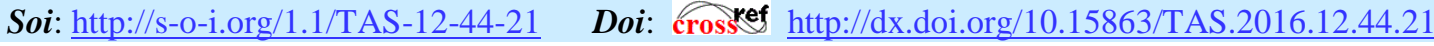

\section{Materials and Methods}

The building of the Mikhailovsky Palace (fig.1), now occupied by the State Russian Museum, was built by the architect Carlo Rossi as the residence of the fourth son of Emperor Paul I Mikhail Pavlovich Romanov. The palace, located in the heart of St. Petersburg, was built 6 years - from 1819 to 1825 [4].

It first 79 years, the palace served as the residence of the Grand Duke Mikhail Pavlovich and his wife Helena (Charlotte Wurttembergsky). A mezzanine (2nd floor) held the ceremonial suite of rooms: ballrooms in the west, and the state rooms on the eastern side of the palace. Everyday living quarters of the grand-ducal family were located on the 1st floor. In the basement (Cellars) floor of the palace housed various services. Over time, at the request of the owners of the palace interiors began to change. In the middle of 1830 on the new interiors of the architect Andrew Stackenschneider in 1840 Gerald Bosse, Alexander Ludwig Bonstedt and Jurkiewicz in the 1850s, and in 1963 - Robert Gedike. Since the mid-1860s by the architect of the palace are Georg Preuss, and then by his son Constantine [5, p. 345-359].

Each of the architects had made its contribution to the formation of the palace interiors. In January 1895, the palace was purchased from the heir's daughter Mikhail Pavlovich to the state treasury of the Russian Empire. Among the various proposals for the use of the palace had won a bid vice-president of the Imperial Academy of Arts Ivan Tolstoy to establish a museum of Russian art. And April 13, 1895, Emperor Nicholas I issued a decree "On establishment of the establishment of special called "Russian Museum of Emperor Alexander III" and to provide for this purpose in the acquired treasury Mikhailovsky Palace with all the wings belonging to him, services, and a garden." [6]. The works on placing the museum in the palace premises led 30- 


\begin{tabular}{|c|c|c|c|c|c|c|}
\hline Impact Factor: & $\begin{array}{l}\text { ISRA (India) } \\
\text { ISI (Dubai, UAE } \\
\text { GIF (Australia) } \\
\text { JIF }\end{array}$ & $\begin{array}{r}=1.344 \\
=0.829 \\
=0.564 \\
=1.500\end{array}$ & $\begin{array}{l}\text { SIS (USA) } \\
\text { PИНЦ (Russia) } \\
\text { ESJI (KZ) } \\
\text { SJIF (Morocco) }\end{array}$ & $\begin{array}{l}=0.912 \\
=0.234 \\
=1.042 \\
=\mathbf{2 . 0 3 1}\end{array}$ & $\begin{array}{l}\text { ICV (Poland) } \\
\text { PIF (India) } \\
\text { IBI (India) }\end{array}$ & $\begin{array}{l}=6.630 \\
=1.940 \\
=4.260\end{array}$ \\
\hline
\end{tabular}

year-old graduate of the St. Petersburg Academy of Arts architect Vasily Svinyin. In the course of works on the reconstruction of the interiors of the former palace have undergone significant changes. Ballroom and large dining room was rebuilt in the academic halls. In these halls of the window openings and arranged overhead lighting through skylights arranged were laid. Not only remained intact main staircase and White Hall [7, p.16]. The grand opening of the museum took place on 7 (19) in
March 1898 [8]. The first exhibition consisted of 5 thousand exhibits in 37 halls of the Mikhailovsky Palace. Visitors were available 445 paintings (including 80 paintings from the Hermitage, and 120 of the Meeting of the Academy of Fine Arts), 111 sculptures, 981 sheet graphics, and an extensive collection of Russian icons and objects of decorative art. It has become an important cultural event of the time - in Russia there was a national museum of Russian culture [9].

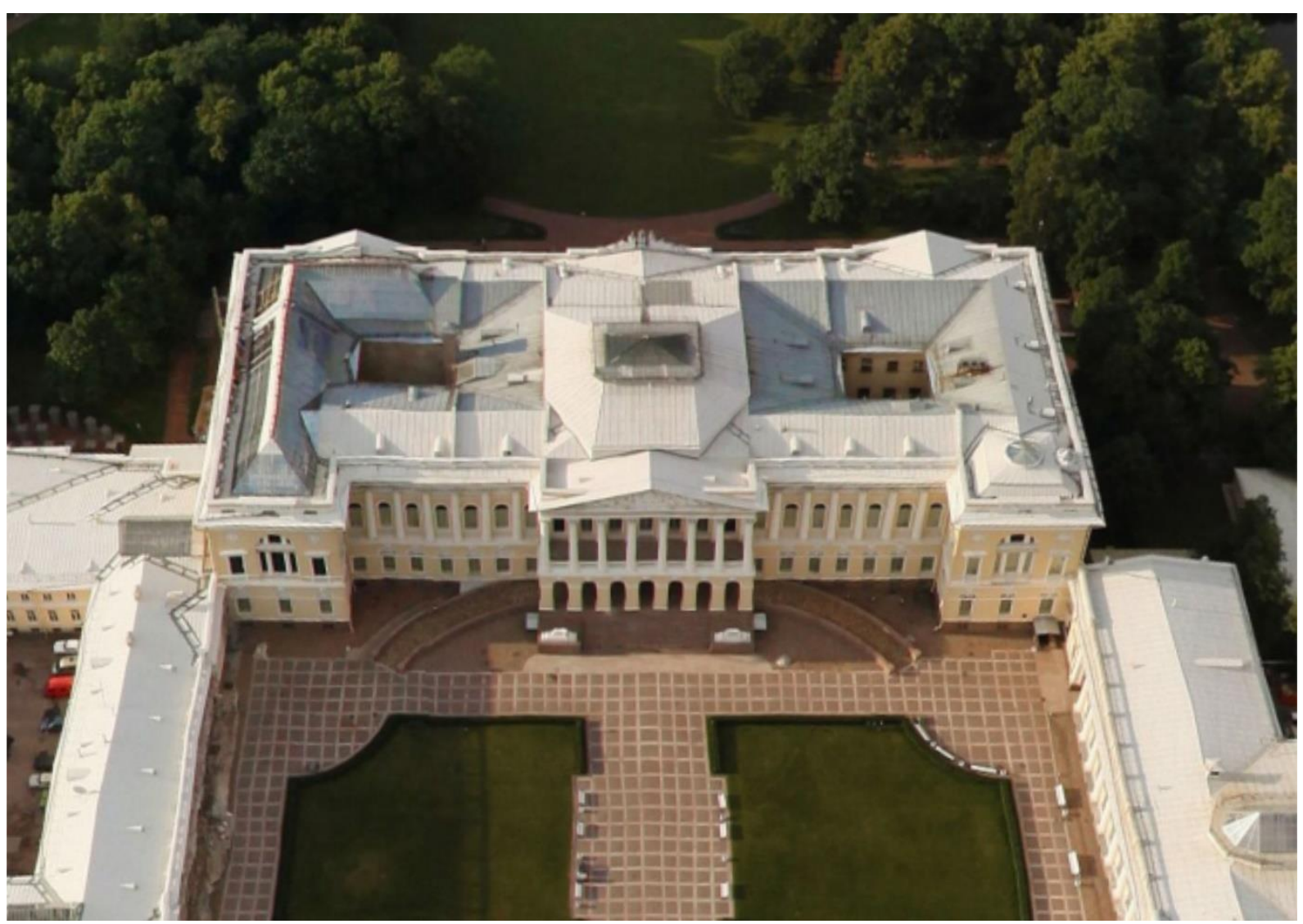

Figure 1 - The Mikhailovsky Palace. The view from the helicopter (Yandex. Maps)

Over time, the Museum has developed and expanded. At the site of a pre-existing Manege wings, the Stables building and Laundry home in 1903-1916 under the project of the same architect Basil Svinyin were erected building of the Ethnographic Department and the Memorial Hall. Today these buildings take an independent Russian Museum of Ethnography. In the 1901-1902 year by the Catherine Canal (now Griboyedov Canal) was built by the architect Svinyin four-story apartment house employees of the Russian Museum. In the years 1914 - 1919 by the architect Leonty Benois and Sergey Ovsyannikov was built with Palace of the Arts side Griboyedov Canal (now the Benois Wing), shutting the complex of buildings and complete the formation of a complex of buildings of the Russian Museum.
Nationalized in 1918, the museum got its modern name - the State Russian Museum. In 1925 he arranged the so-called "Repinsky room" (now the "Hall of the State Council") was set up in the west wing of the building civil engineer Mikhail Kritsky. It is a vast two-story room with a skylight. Under the direction of architect Vladimir Taleporovsky project connections western wing was designed in 1934 (Rossi wing) to the exhibition building on the Griboyedov Canal (the Benois Wing). On the same basement and the main project of the palace buildings were converted to accommodate offices and wardrobes. To lift visitors from the ground floor to the level of the 1st floor, two new staircases were organized. The project was implemented under the supervision of the superintendent technician V.N. Maslennikov in 1939. Since that time, significant 


\begin{tabular}{|c|c|c|c|c|c|c|}
\hline Impact Factor: & $\begin{array}{l}\text { ISRA (India) } \\
\text { ISI (Dubai, UAE } \\
\text { GIF (Australia) } \\
\text { JIF }\end{array}$ & $\begin{array}{l}=1.344 \\
=0.829 \\
=0.564 \\
=1.500\end{array}$ & $\begin{array}{l}\text { SIS (USA) } \\
\text { PИНЦ (Russia) } \\
\text { ESJI (KZ) } \\
\text { SJIF (Morocco) }\end{array}$ & $\begin{array}{l}=0.912 \\
=0.234 \\
=1.042 \\
=2.031\end{array}$ & $\begin{array}{l}\text { ICV (Poland) } \\
\text { PIF (India) } \\
\text { IBI (India) }\end{array}$ & $\begin{array}{l}=6.630 \\
=1.940 \\
=4.260\end{array}$ \\
\hline
\end{tabular}

alterations in the State Russian Museum building was carried out [10].

Despite the fact that the State Russian Museum for the past 20 years has significantly increased their area due to the transfer of the Stroganov Palace, Mikhailovsky Castle, the Marble Palace and the Summer Garden [11-13], there remains relevant increase of exhibition space in the main building. In 2002, the workshop has been prepared by Mikhail Filippov overlapping project courtyards and reconstruction of the attic in the exhibition space
[14]. The project was not implemented, and to date no longer meet the requirements of modern legislation on the protection of monuments and on the safety of buildings and structures legislation. In the years 2014-2016 by the order of JSC "LenPolproekt" and Federal budget institution of culture "State Russian Museum" Architectural bureau by Victor Sakhnovsky (AMS) drafted a device courtyard spaces and adjoining buildings for modern use, with the inclusion of these spaces are available for visitors to the exhibition area [15] (fig.2).

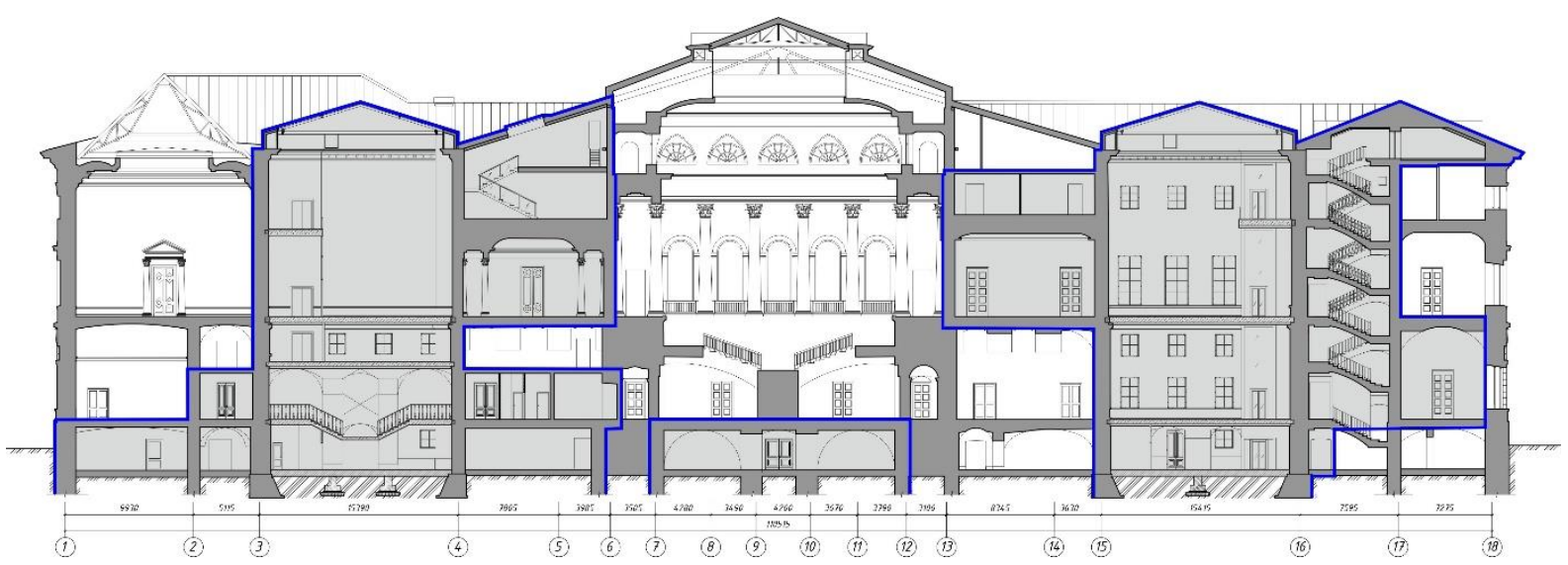

Figure 2 - The Mikhailovsky Palace. A longitudinal section (AMS).

One of the important problems solved by this project is the task of organizing a comfortable access to the museum of persons with disabilities (the socalled low-mobile groups of visitors). For those who find it difficult to use the stairs, arranged entrance ramp descending to the level of the basement, where are wardrobes, offices and other points of service of visitors. The shape of the ramp follows the shape of the existing palace of the carriage lifting (fig.3). With this solution begins to be used have not involved the space in the basement, under the stairs from the main facade.

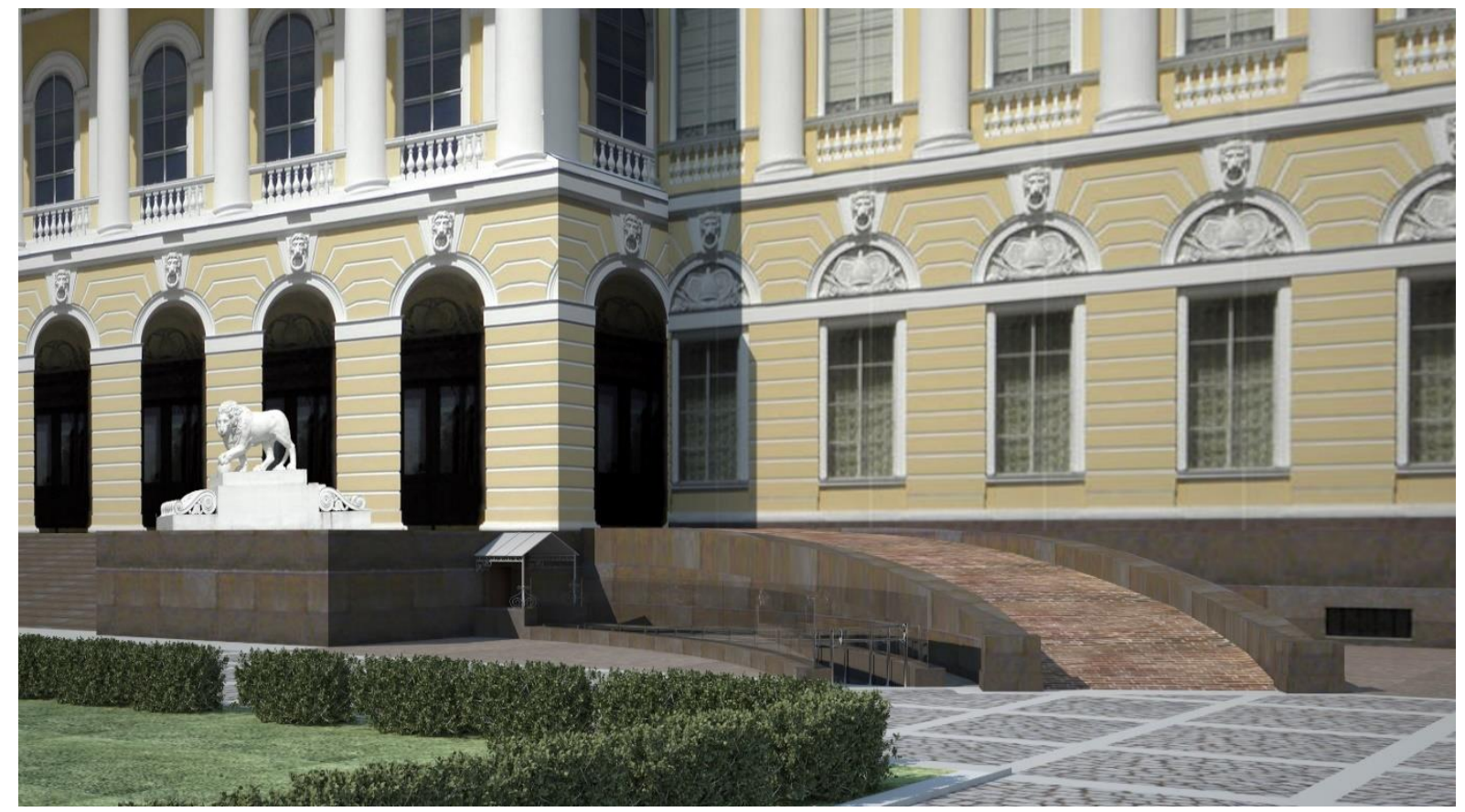

Figure 3 - The ramp and carriage entrance (AMS).

ISPC Generalization of scientific results, 


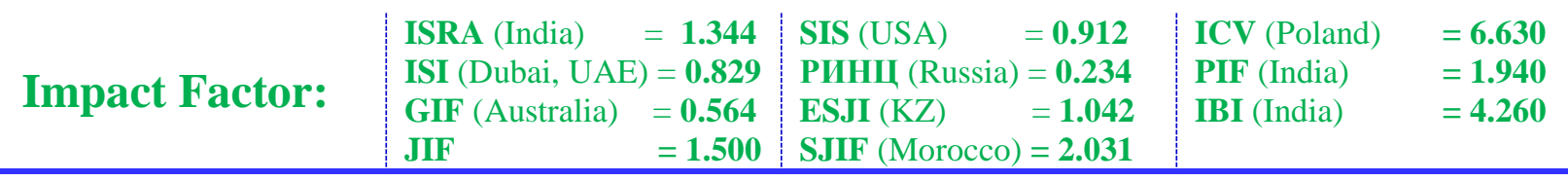

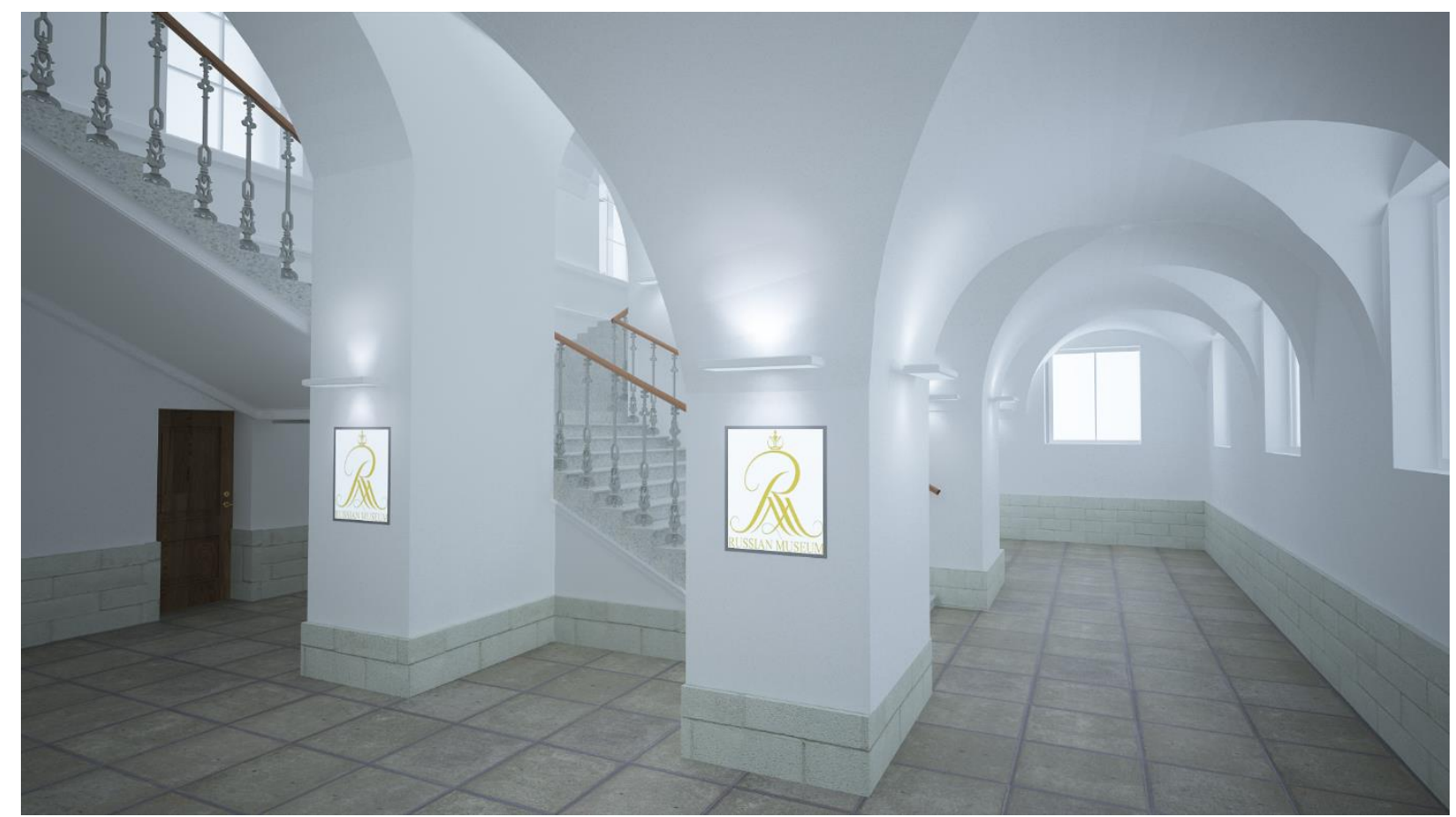

Figure 4 - The main stairs (AMS).

West courtyard as a result of the proposed project will play an important infrastructure for the Museum of the load. Firstly, it will provide access to visitors from the basement of the building to the top of the exposure on the 1st floor. Existing 30-ies of the last century, the narrow stairs to lift the visitors to the beginning of exposure, replaced three space landing sweeping staircase, repeating the shape of the inside of the grand staircase of the Palace (fig.4). The space of the 1st floor and mezzanine floor above

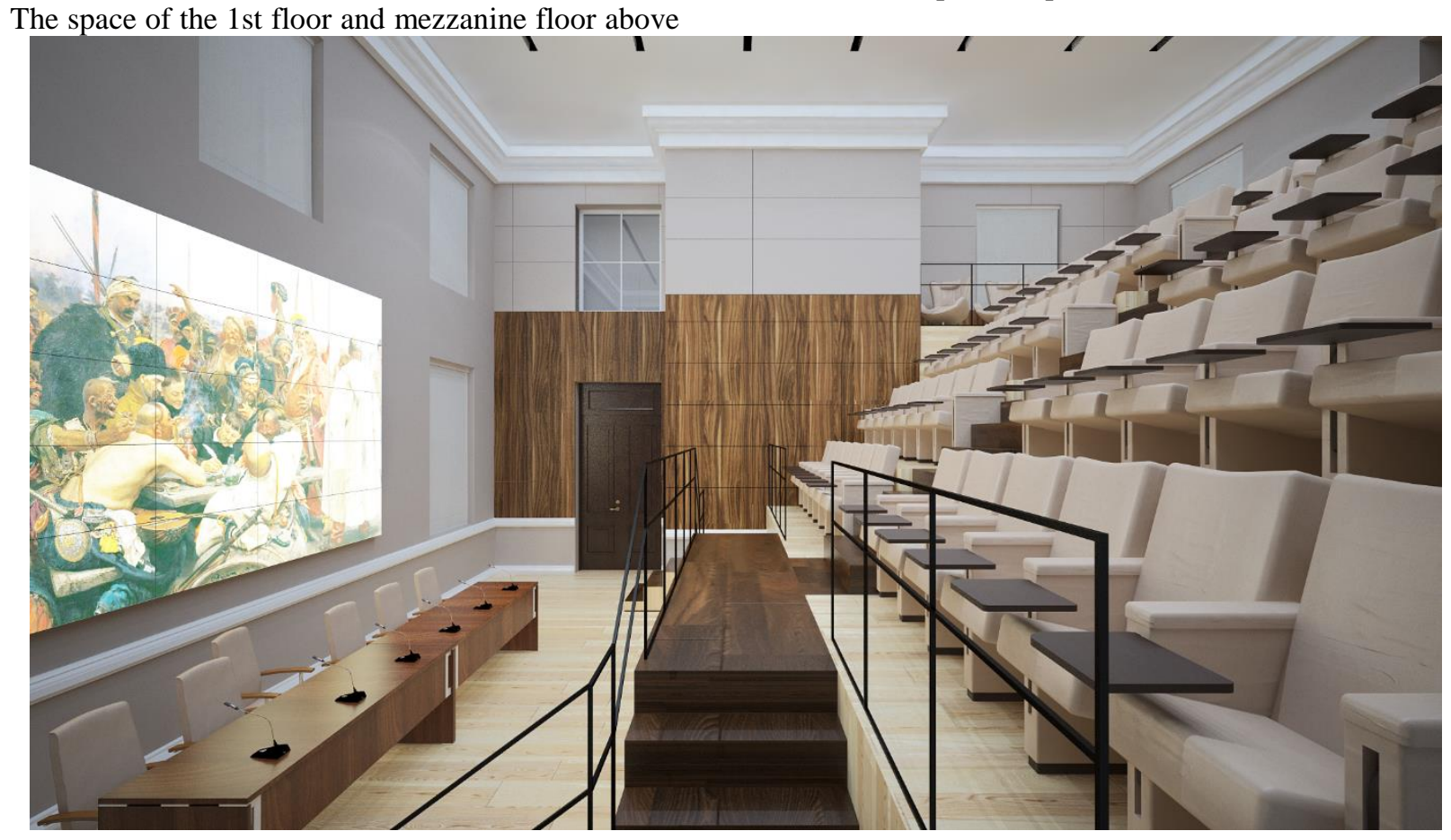

Figure 5 - The conference hall for 80 seats (AMS).

ISPC Generalization of scientific results,

the staircase takes again organized a conference hall with 80 seats (fig.5). Location of the hall, its proximity to the entrance, as well as some of its isolation from the main exhibition, allows the use of the hall in the days and hours when the main museum exhibition is closed to the access of visitors. Thus it is achieved the second objective of the project - to arrange a convenient meeting room, which has space for persons on wheelchairs. 


\begin{tabular}{|c|c|c|c|c|c|c|}
\hline Impact Factor: & $\begin{array}{l}\text { ISRA (India) } \\
\text { ISI (Dubai, UAF } \\
\text { GIF (Australia) } \\
\text { JIF }\end{array}$ & $\begin{array}{r}=1.344 \\
=0.829 \\
=0.564 \\
=1.500\end{array}$ & $\begin{array}{l}\text { SIS (USA) } \\
\text { PИНЦ (Russia) } \\
\text { ESJI (KZ) } \\
\text { SJIF (Morocco) }\end{array}$ & $\begin{array}{l}=0.912 \\
=0.234 \\
=1.042 \\
=2.031\end{array}$ & $\begin{array}{l}\text { ICV (Poland) } \\
\text { PIF (India) } \\
\text { IBI (India) }\end{array}$ & $\begin{array}{l}=6.630 \\
=1.940 \\
=4.260\end{array}$ \\
\hline
\end{tabular}

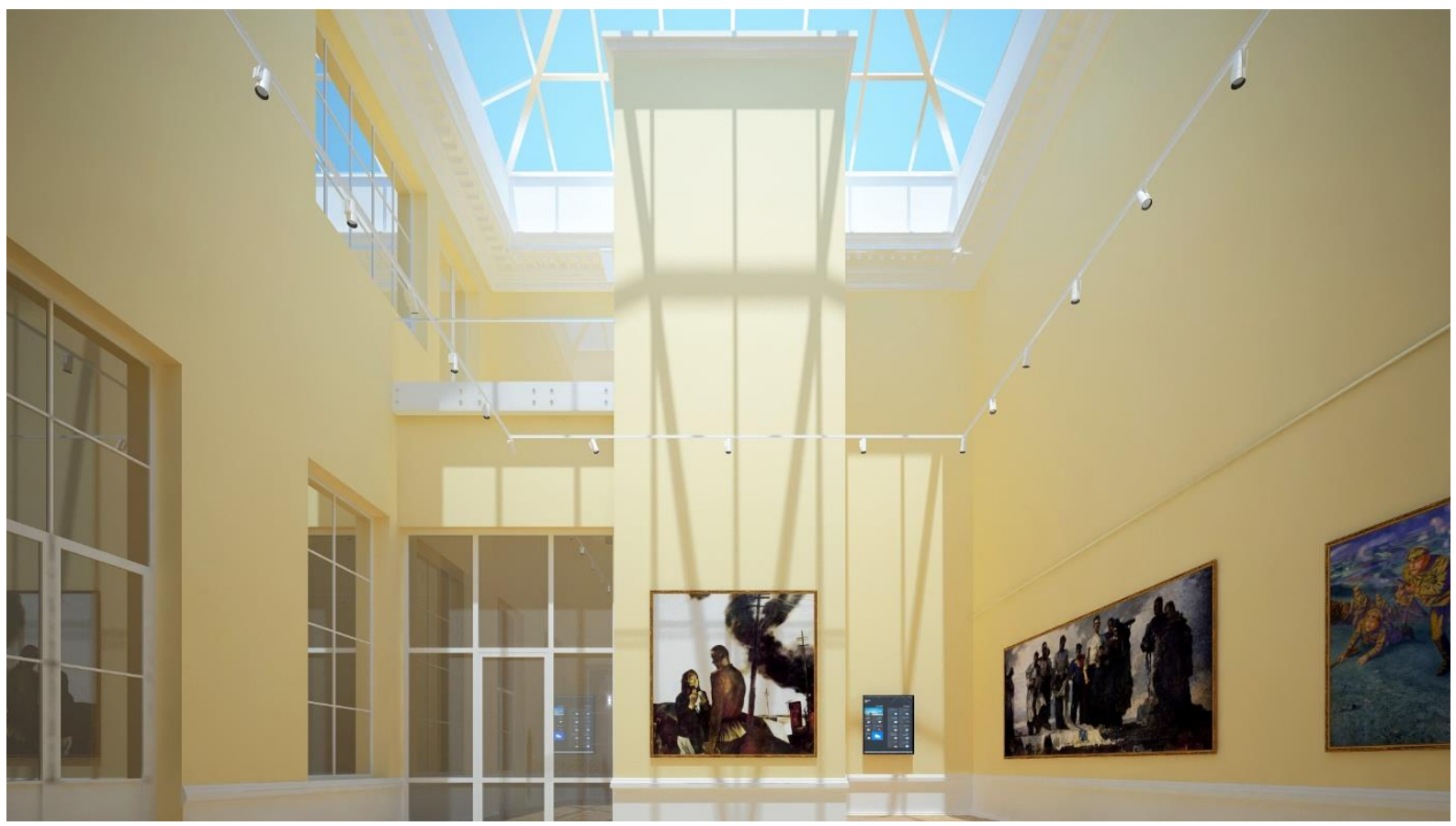

Figure 6 - The Western courtyard. Exhibition hall on the second floor with lift and security zone for the disabled (AMS).

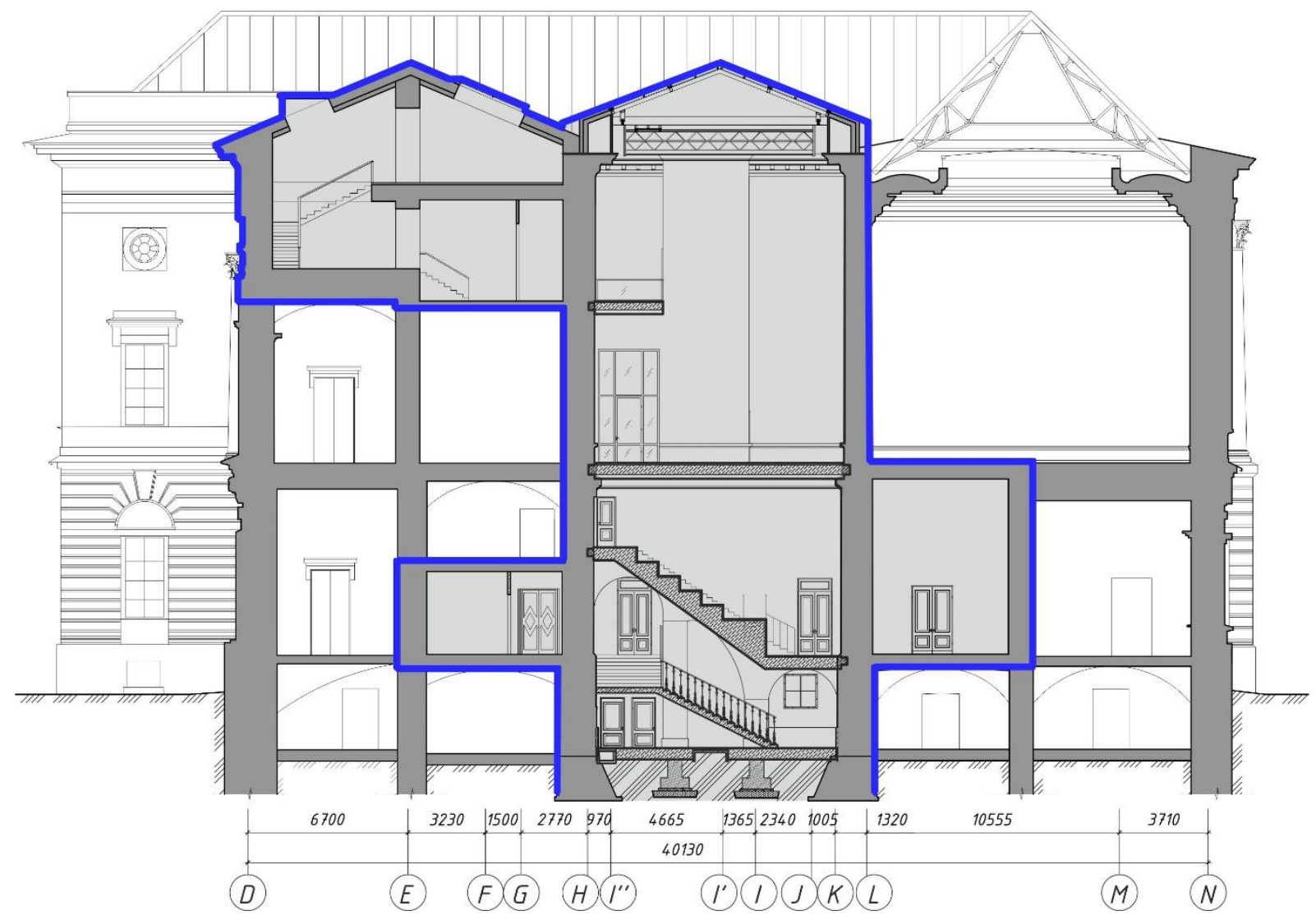

Figure 7 - A cross-section of the Western courtyard (AMS).

ISPC Generalization of scientific results, 


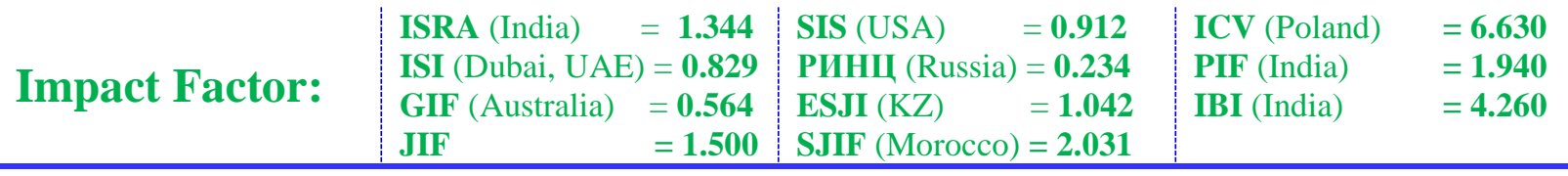

The premises of the former museum of the library service, taking into account the disclosure of previously existing doorways and transfer of the premises to accommodate the exhibition, allow you to restore a solid suite of exhibition rooms on the 1 st floor.

At the level of the second floor in the courtyard organized double-height exhibition hall, access to which is provided in addition to a lift from one of the existing exhibition halls through reorganization of the picture window in the glass door (fig.6, 7).
The existing and currently unused chimney of the former boiler house is maintained by its dimensions and is used for the organization of the new premises of the ventilation system.

East courtyard is covered at the level of the first and second floors, which allows the museum to receive two new exhibition halls. Entrance to the new hall on the ground floor, will be organized through a fund drawing room that allows you to turn the hall with a unique painted the ceiling in the number of premises that are open to the public access (fig.8-10).

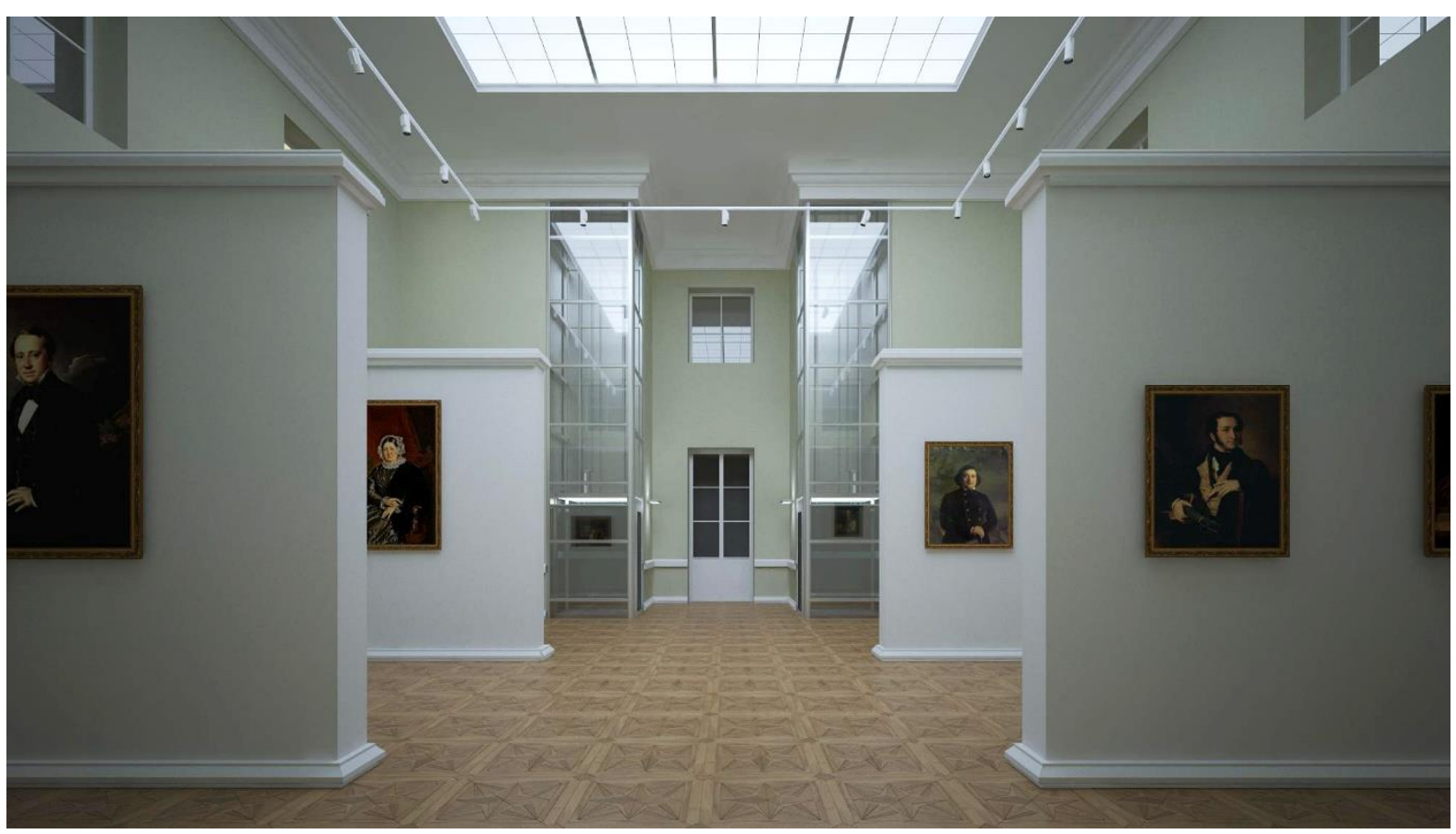

Figure 8 - The Eastern courtyard. Exhibition hall, 1st floor (AMS).

To facilitate vertical movement of the visitors in the courtyards arranged lifts. In the western courtyard located a utility lift, also performs the lift function to move the visitors with limited mobility. In case of emergency, this lift can be used to move the fire brigade. East courtyard equipped with two panoramic passenger elevators, also allow the transport of persons in wheelchairs. Since the elevators that do not fulfill the role of the court lifts to move the fire brigade, they were designed in glass shafts, allowing visitors to inspect the new facilities during the ascent and descent of the elevator. Exit to the balcony, located at the 3rd floor in the two courts are available only for the museum employees working in located on these floors, restoration workshops.
Glass ceiling households are hipped glass pyramids, is based on the existing walls of the building, or rather the height of the point of the pyramid corresponds to the lowest point of the upper ridge of the roof of the museum. This solution makes the "pyramid" unnoticed from any point that provides the immutability of the external appearance of the building of the Russian Museum.

Emergency exits, are housed in the ends, allow the museum to bring into line with modern standards of fire safety.

Proposals offered by the architectural bureau of Sakhnovsky allow the State Russian Museum to receive more than 750 square meters of new exhibition spaces (including 380 - located in the yards themselves). 


\begin{tabular}{|c|c|c|c|c|c|c|}
\hline Impact Factor: & $\begin{array}{l}\text { ISRA (India) } \\
\text { ISI (Dubai, UAF } \\
\text { GIF (Australia) } \\
\text { JIF }\end{array}$ & $\begin{array}{r}=1.344 \\
=0.829 \\
=0.564 \\
=1.500\end{array}$ & $\begin{array}{l}\text { SIS (USA) } \\
\text { PИНЦ (Russia) } \\
\text { ESJI (KZ) } \\
\text { SJIF (Morocco) }\end{array}$ & $\begin{array}{l}=0.912 \\
=0.234 \\
=1.042 \\
=2.031\end{array}$ & $\begin{array}{l}\text { ICV (Poland) } \\
\text { PIF (India) } \\
\text { IBI (India) }\end{array}$ & $\begin{array}{l}=6.630 \\
=1.940 \\
=4.260\end{array}$ \\
\hline
\end{tabular}

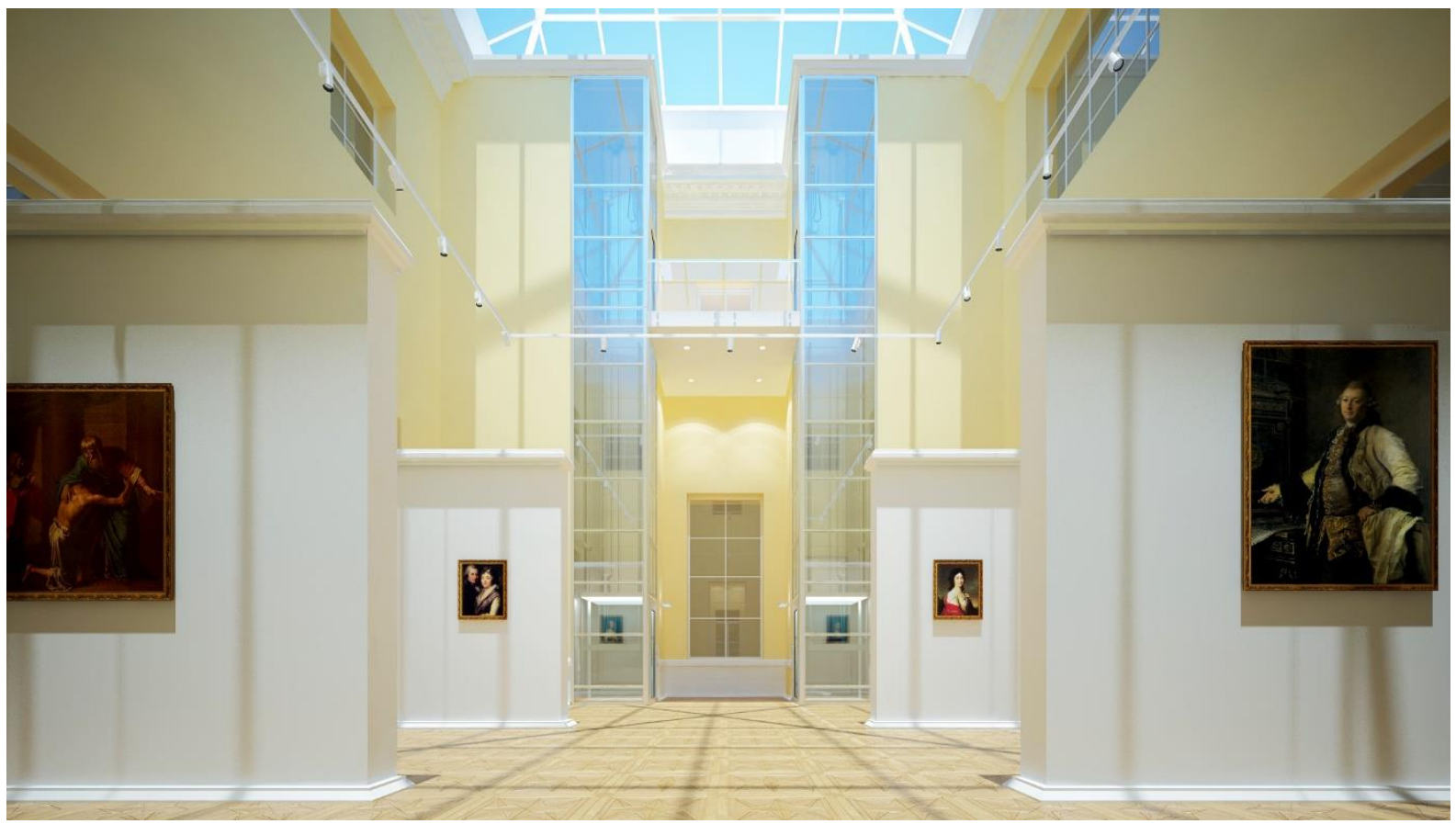

Figure 9 - The Eastern courtyard. Exhibition hall, 2st floor (AMS).

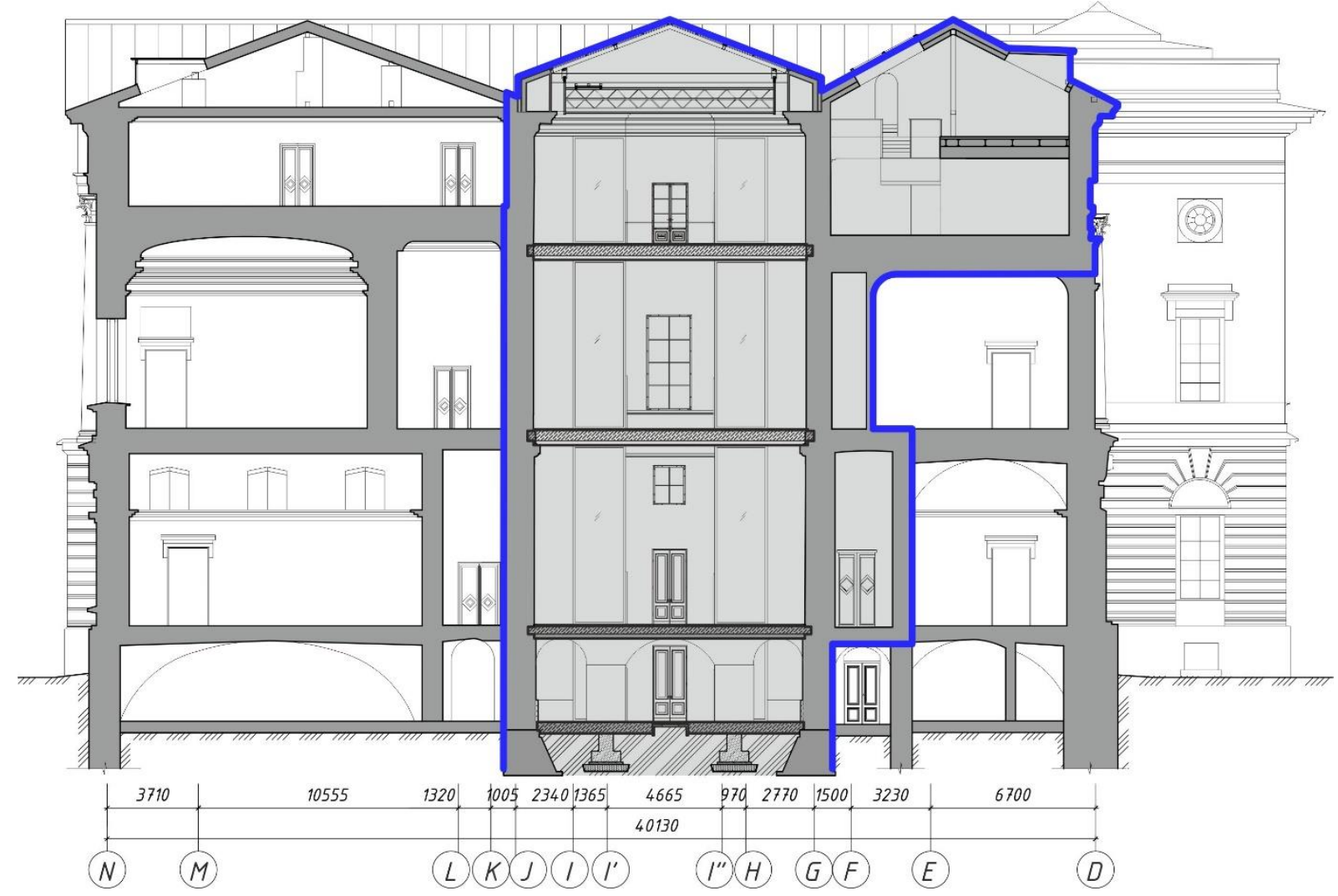

Figure 10 - A cross-section of the Eastern courtyard (AMS).

\section{Conclusion}

In its work, the authors of the project adhered to the principle of minimum implementation of a monument structure. Reconstruction of window openings in the door are made in the lowest possible amounts that provide the necessary communication. For organizations new ways to move us mainly provides disclosure of pre-existing historical doorways.

ISPC Generalization of scientific results, 
The newly created interiors in style reminiscent of the surrounding rooms. This is done in order not to distract visitors from the main purpose of the visit of the museum - acquaintance with the masterpieces of Russian painting, sculpture and decorative arts.

The new project, as opposed to the project in 2002, provides for the preservation of the unique Palace of rafter system. Unique proposed and implemented by architect Carlo Rossi and Vasily Svinyin now not only keeps the load from the roof of a building, but also places a load-bearing structure of the ceiling of the underlying floors of the museum exhibition.

Newly arranged overlaps of the 1st floor are based mainly on the new columns (4 and 2 in the west - in the eastern courtyard). This solution allows you to minimize the load on the existing walls of the newly constructed floors. On the wall, with the proposed solution, based only overlap 2 floors and glass " pyramid " atriums.

The successful result of historical and cultural examination of the project, provided by the Russian legislation on the protection of monuments [16], approval by the Ministry of Culture of Russian Federation, as well as the result of the state examination of project documentation, provided by town planning legislation [17], confirm the validity of the proposed project in the architectural bureau of Sakhnovsky solutions.

Further development of the proposed project can be a transfer of part of the administrative buildings and the restoration of the building erected in 1901-02 under the project of Vasily Svinyin for museum employees [15]. Freed Russian housing premises, together with the overlap of the inner court of the same body, may become the new main entrance to the Russian Museum. Such an arrangement would allow a more rational distribute flow of visitors because the main entrance will be located in the center of the museum complex.

\section{Acknowledgments}

The authors express their gratitude to the staff of the architectural studio, that took part in the preparation of project documentation: the chief designer Sergei Nasonov; architects: Catherine Akhramenko, Irina Borodenko, Natalia Koryukina, Alla Samarkina, Elina Skokova; designers: Mikhail Demchenko, Dmitry Yakovlev; engineers Anatoly Akhramenko and Sergey Yatsenko; as well as to oversee the project: Vladimir Bazhenov, Irina Teterina, Irina Govorunova (State Russian Museum), Has Magamadov and Gennady Davidov (JSC "LenPolproekt").

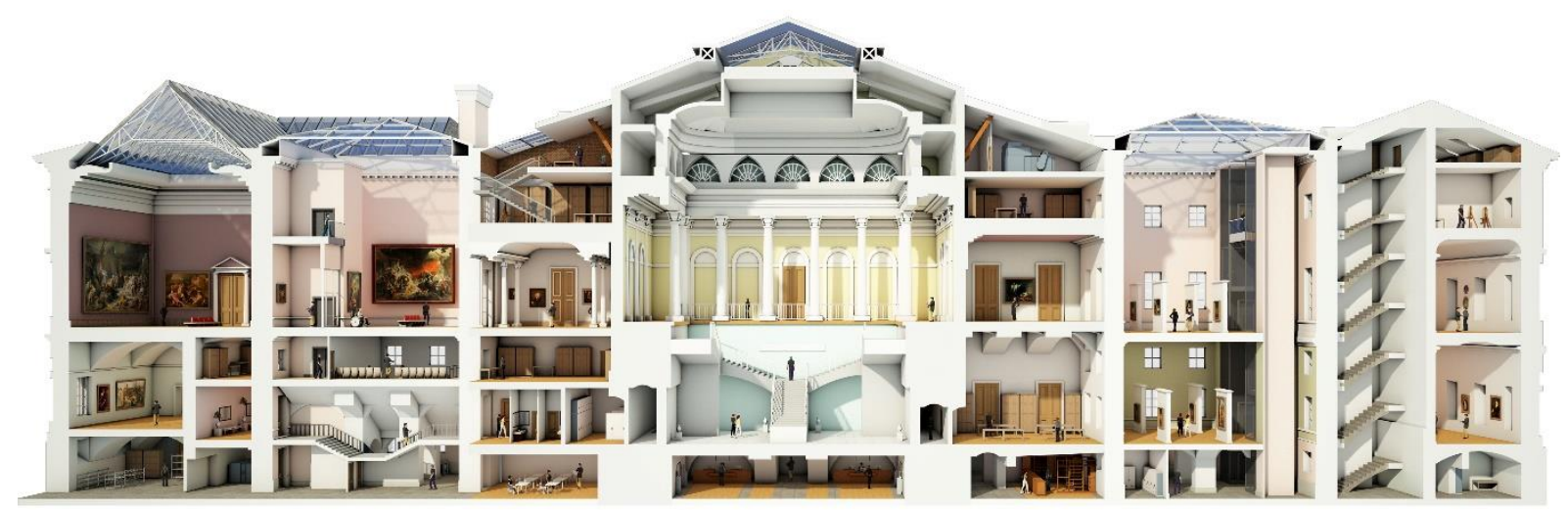

Figure 11 - The Mikhailovsky Palace. A longitudinal section (Architectural bureau by Victor Sakhnovsky).

\section{References:}

1. Ahunov VM, Kazakov NP (2014) Dinamika poseshhaemosti Gosudarstvennogo Russkogo muzeja i vozmozhnye mery po ee uvelicheniju [Attendance dynamics for the State Russian
Museum and possible measures for its increase dynamics of the attendance of the State Russian Museum and the possible measures to increase 
its] // Vestnik LGU im. A.S. Pushkina - 2014. — №1 - p.38-44.

2. Koziev VN, Petrunina LY (2008) Dinamika poseshhaemosti hudozhestvennyh muzeev (1985-2006) // Sociologicheskie issledovanija [Dynamics attendance art museums (19852006)] // Sociologicheskie issledovanija. 2008. - №10. - p.104-113

3. Shekova E (2012) Changes in Russian museum attendance: 1980-2008 // Museum Management and Curatorship. - 2012. - Vol. 27. № 2. p. 149-159.

4. Grimm GG (1936) Raboty Karla Rossii po Mihajlovskomu dvorcu, ploshhadi i ulice [Carlo Rossi in Mikhailovsky Palace, the square and the street] // Arhitektura i stroitel'stvo Leningrada. - 1936. - № 2. - p. 44-51.

5. Parskevich ZA (2015) Velikoknjazheskij Mihajlovskij dvorec. 1925-1895 [GrandMikhailovsky Palace. 1925-1895] / Dvorcy Romanovyh kak pamjatniki istorii i kul'tury. Materialy mezhdunarodnoj konferencii. 7-9 oktjabrja 2013 [Dvortsy Romanov as monuments of history and culture. Proceedings of the international conference. October 7-9, 2013]. St. Petersburg Publisher "European House". 2015 - 540p.

6. (1895) Ob uchrezhdenii osobogo ustanovlenija pod nazvaniem «Russkij muzej imperatora Aleksandra III» i o predstavlenii dlja sej celi priobretjonnogo v kaznu Mihajlovskogo dvorca so vsemi prinadlezhashhimi $\mathrm{k}$ nemu fligeljami, sluzhbami i sadom. Imennoj Vysochajshij Ukaz Imperatora Nikolaja II ot 13 aprelja 1895 goda [On the establishment of the establishment of a special titled "Russian Museum of Emperor Alexander III» and to submit for this purpose acquired by the treasury of the Mikhailovsky Palace with all the wings belonging to him, services, and a garden. Name of the Supreme Decree of Emperor Nicholas II on April 13, 1895] // Polnoe sobranie zakonov Rossijskoj imperii, sobranie tret'e [Complete Collection of Laws of the Russian Empire, the third meeting]. — T. XV, — № 11532. — p. 189.

7. Petrov GF (1972) Russkij muzej [The Russian Museum]. - Leningrad: Lenizdat, 1972. - 54 p.

8. Polovtsov AV (1900) Progulka po Russkomu muzeju Imperatora Aleksandra III v S.Peterburge [Walk on the Russian Museum of Emperor Alexander III in St. Petersburg]. M .: Type. T-va Kushnereva, 1900. - 173 p.

9. Tsvetaeva MN (2009) Russkij muzej v kontekste filosofii kul'tury [Russian Museum in the context of the philosophy of culture] // Vestnik Sankt-Peterburgskogo universiteta.
Serija 6. Politologija. Mezhdunarodnye otnoshenija. - 2009. - 2 (June). - p.238241.

10. Bazhenov VP, Teterina IV (2016) Russkij muzej. Vchera. Segodnja. Zavtra. Restavracija fasadov Mihajlovskogo i inter'erov Mramornogo dvorcov [Russian Museum. Yesterday. Today. Tomorrow. The restoration of the facades and interiors of the Mikhailovsky Marble Palaces] // Vestnik. Zodchij 21 vek. 2016. — №1 (58). - p. 38-43.

11. Bazhenov VP (2009) Russkij muzej XXI veka. Garmonija dvorcov i parkov [Russian Museum of the XXI century. Harmony palaces and parks] // Vestnik. Zodchij 21 vek [Herald. Architect of the 21st century]. - 2009. - №2 (31). - p. 62-67.

12. Gusev VA (1997) Russkij muzej na poroge XXI veka [Russian museum on the threshold of the XXI century]. St. Petersburg: St. Petersburg Humanitarian University of Trade Unions.1997. - 23p.

13. (1999) Dvorcy Russkogo muzeja [Palaces of the Russian Museum]: / State. Eng. Museum; [Ed. and Prepare. Kalnitskaya E. Y., Petrov E. N.]. - SPb: Palace Editions, 1999. — 266p.

14. Fedotova NY (2014) Sovremennye tendencii muzejnoj modernizacii: analiz novyh arhitekturnyh proektov [Modern museum modernization trends: analysis of new architectural projects] // Artikul't — 2014. — 4 (16). - p. 49-53.

15. Sakhnovsky VA, Polovtsev IN (2016) Prisposoblenie dvorov s muzejnotehnologicheskoj modernizaciej Mihajlovskogo dvorca Russkogo muzeja [Accommodation yards from the museum and the technological modernization of the Mikhailovsky Palace Russian Museum] // Vestnik. Zodchij 21 vek. - 2016. — № 2-2 (59). — p. 46-48.

16. (2002) Ob ob'ektah kul'turnogo nasledija (pamjatnikah istorii i kul'tury) narodov Rossijskoj Federacii. Federal'nyj Zakon ot 25 ijunja 2002 goda №73-FZ [On the objects of cultural heritage (monuments of history and culture) of the peoples of the Russian Federation. Federal Law of June 25, 2002 №73FZ] // Sobranie zakonodatel'stva Rossijskoj Federacii. - 2002. — №26. - p.2519

17. (2005) Gradostroitel'nyj kodeks Rossijskoj Federacii. Federal'nyj Zakon ot 29 dekabrja 2004 goda №190-FZ [Town Planning Code of the Russian Federation. Federal Law of December 29, 2004 №190-FZ] // Sobranie zakonodatel'stva Rossijskoj Federacii. — 2005. — №1 (chast' I). — p.16. 